\title{
The coexistence of Acheulean and Ancient Middle Palaeolithic techno- complexes in the Middle Pleistocene of the Iberian Peninsula
}

\author{
Manuel Santonja a, , Alfredo Pérez-González a , Joaquín Panera ${ }^{\text {b }}$, Susana Rubio-Jara ${ }^{\text {b }}$, \\ Eduardo Méndez-Quintas ${ }^{\mathrm{c}}$ \\ ${ }^{a}$ CENIEH (Centro Nacional de Investigación sobre la Evolución Humana), Paseo Sierra de Atapuerca, s/n, 09002 Burgos, Spain \\ ${ }^{\mathrm{b}}$ IDEA (Institute of Evolution in Africa), Museo de los Orígenes, Plaza de San Andrés 2, 28005 Madrid, Spain \\ ${ }^{\mathrm{c}}$ Escuela Interuniversitaria de Posgrado en Evolución Humana, Universidad de Burgos, C/ Juan de Austria 1, 09001 Burgos, Spain
}

\section{A R T I C L E I N F O}

Article history:

Available online $\mathrm{xxx}$

Keywords:

Iberian Peninsula

Acheulean

Middle Palaeolithic

Middle Pleistocene

\begin{abstract}
A B S T R A C T
Two clearly differentiated techno-complexes can be recognised in the Iberian Peninsula during the second half of the Middle Pleistocene: the Acheulean and the Middle Palaeolithic. In this paper we present the current state of research on both technological entities, and propose that they represent two different industrial traditions. The Acheulean, a techno-complex that originated and developed in Africa, is considered to have reached Western Europe via Gibraltar, and developed only to a limited extent. In contrast, relict populations with a different technological tradition would have been present on the European continent since the late Early Pleistocene and developed a technological tradition was based on the development of chaînes operatoire of débitage. From MIS 10 on these industries had reached a high degree of complexity and diversity.
\end{abstract}

(c) 2015 Elsevier Ltd and INQUA. All rights reserved.

\section{Introduction}

The Iberian Peninsula has only lately begun to play a leading role in the most recent debates about the evolution of the European Ancient Palaeolithic (i.e. Otte, 1996; Jaubert, 1999; Roebroeks, 2006; Delagnes et al., 2007; Hopkinson, 2007; Sharon, 2007; Rolland, 2010). The historical development of the discipline throughout the 19th and 20th centuries traditionally took place in France, where the concepts of the Acheulean and Mousterian were born (Sackett, 1981; Monnier, 2006; Groenen, 2008). Although investigations in Africa have dramatically altered our notion of the Acheulean techno-complex in recent decades (Isaac, 1969, 1972; Gowlett, 1986; Clark, 1994; Lycett and Gowlett, 2008; Diez-Martín and Eren, 2012), we believe that previous schemes underpin many hypothesis regarding the technological traditions documented in the Early and Middle Pleistocene of Southern Europe (Tuffreau, 2004; Nicoud, 2013).

Sites of this period currently known in Spain (Fig. 1) are very numerous in the fluvial formations of the Atlantic basins and have well-established chronologies (Bridgland el al., 2006; Santonja and

\footnotetext{
* Corresponding author.

E-mail address: manuel.santonja@cenieh.es (M. Santonja).
}

Villa, 2006; Santonja and Pérez-González, 2010). This is based both on a detailed knowledge of the morphostratigraphic sequences of the valleys in which they occur, and on a significant number of numerical dates (Santonja and Pérez González, 2002; Falguères et al., 2006; Cunha et al., 2008; Martins et al., 2009, 2010; Panera et al., 2011; Moreno et al., 2012; López-Recio et al., 2013; PérezGonzález et al., 2013; Santonja et al., 2014a,b). The present synthesis regarding the Acheulean and Ancient Middle Palaeolithic is focused on these chronological aspects.

The concept of technocomplex that we adopt here is based on the assessment of the chaînes operatoires (Geneste, 1985; Perlès, 1991; Soressi and Geneste, 2011) and on the distinction between débitage processes focused on the production of flakes from the systematic exploitation of blanks and shaping processes, whose aim was the production of unique tools through the implementation of well defined knapping schemes (Böeda et al., 1990; Boëda, 1991; Inizan et al., 1992; Boëda, 2001). Through making use of these concepts, we believe it is possible to distinguish two clearlydifferentiated techno-complexes in the SW European Pleistocene: the Acheulean and Industries of cores and flakes that ultimately evolved into what is commonly known as the Middle Palaeolithic and Mousterian. The Acheulean techno-complex is characterised by the predominance of chaînes operatoires (c.o.) of façonnage, often lacking exclusive characters, together with independent or 


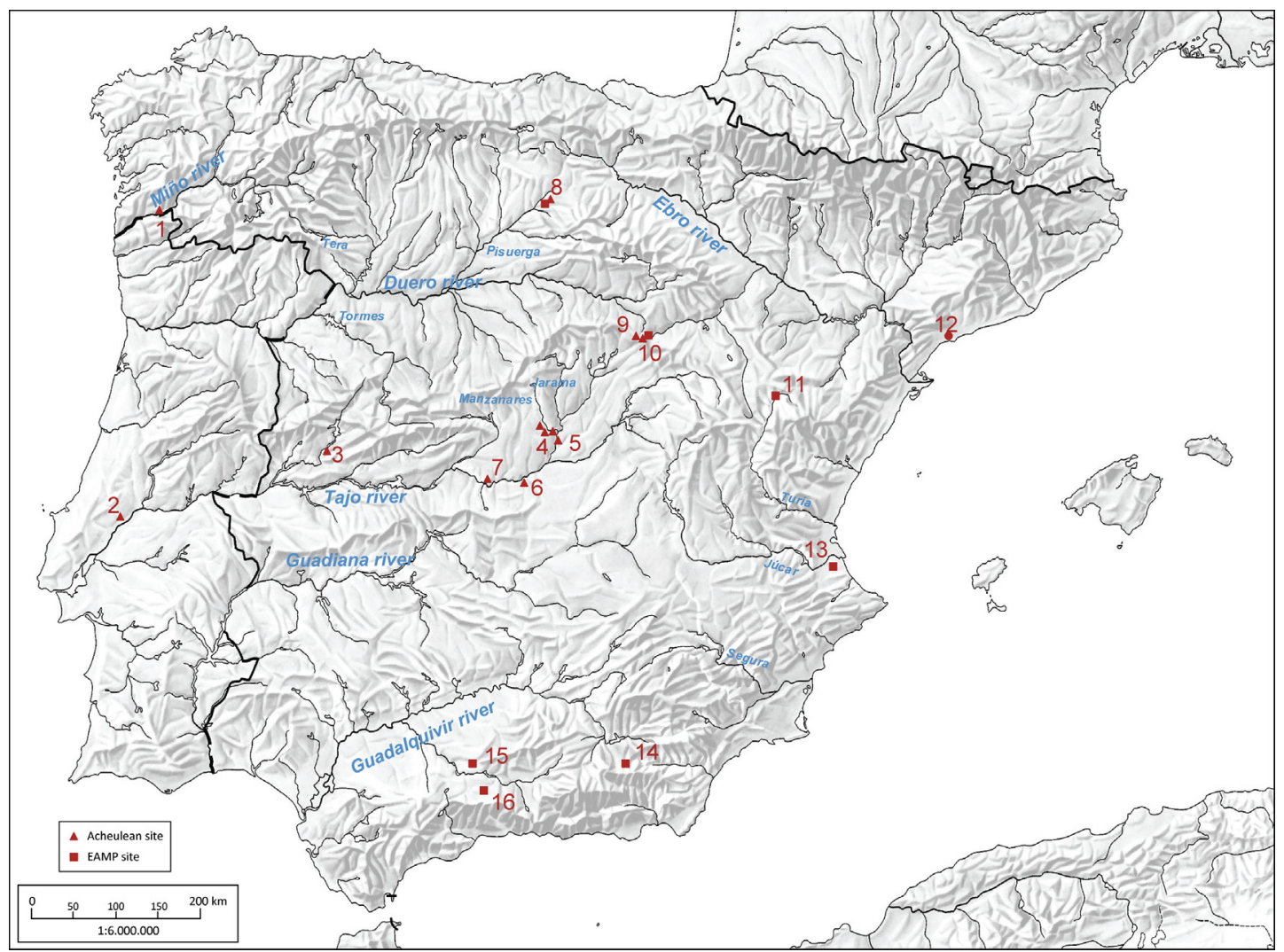

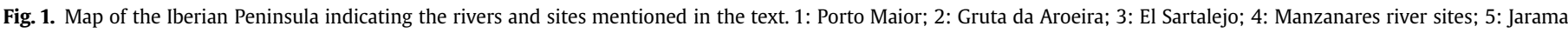

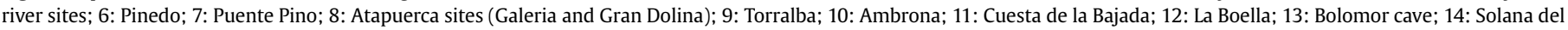
Zamborino; 15: Cueva del Angel; 16: Cave of Las Grajas.

interactive c.o. of débitage (Boëda, 1991). Flake and core industries would assimilate other techno-complexes in which the c.o. of débitage take preference, not excluding the presence of c.o. of façonnage, which can become complex in Mousterian contexts (Boëda, 2001; Molines et al., 2001). Finally, an alternative hypothesis to the traditional evolutionary proposal is discussed, as well as other more recent hypotheses, which define the independent origin of the European lithic industries with bifacial macro-tools.

\section{The European Acheulean. The sequence in the Iberian Peninsula}

In the European continent the Acheulean techno-complex is a phenomenon clearly restricted to the southern regions, the manifestations of which become increasingly weak northwards up the River Rhine, and is unknown in Central Europe and the Russian plain (Fig. 2). This suggests that it probably arrived on the continent via a southern route (Santonja and Villa, 2006; Doronichev and Golovanova, 2010; Bar-Yosef and Belfer-Cohen, 2013; Rocca, 2013).

The Acheulian techno-complex in the Iberian Peninsula and in southern France shows technological features in common with the African Acheulean (Clark, 1994; Sharon, 2007). Shaping is dominant in the c.o. of these industries, and production is often oriented towards obtaining large flakes that can be used as blanks for making large bifacial artefacts. The elaboration of tools by retouch is not common. The essential characteristics of these industries - the presence of cleavers, for instance - remains largely unclear in the more northern latitudes, even in regions originally described as "classic Acheulean", such as the Somme basin in the north of
France, where the techno-complex was first recognised and defined in Europe (Jaubert and Servelle, 1996; Santonja and Villa, 2006; Mourre and Colonge, 2007; Tuffreau et al., 2008; Turq et al., 2010).

The Acheulean is mainly found in open-air sites, and its presence in caves has only been reported from a relatively restricted number of locations, namely, the lowest levels of l'Aragó in southern France, the Gruta de Aroeira in Portugal and, to a lesser degree, in Montmaurin, Haute Garonne, France, and Galería, Atapuerca, Spain (Lumley and Barsky, 2004; Turq et al., 2010; Hoffmann et al., 2013; Ollé et al., 2013; García-Medrano et al., 2014). In the case of Galería, the updated information for the lithic assemblage has been described for complex stratigraphic units (GII and GIII), but it is not defined for the archaeopalaeontological levels (GIIa, GIIb; GIIIa, GIIIb), making it difficult to interpret the intensity of Acheulean presence at this site. In the Iberian Peninsula, the Acheulean lithic industries are equally generally recorded in open air contexts. They reach a high density in certain fluvial formations of the Atlantic coast, from the Miño river (Galicia) to the Guadalquivir river (Andalucía) (Santonja and Pérez-González, 2002, 2010). Sometimes, high concentrations of lithic industries can be observed, for which parallels can only be found in Africa (Fig. 3).

\subsection{The Tagus Basin sequence}

One example, which may be viewed as representative of the evidence from all these basins, is that of the Tagus Basin, especially in the middle course of the River Tagus and the lower courses of the Manzanares and Jarama rivers (Table 1). The largest known 


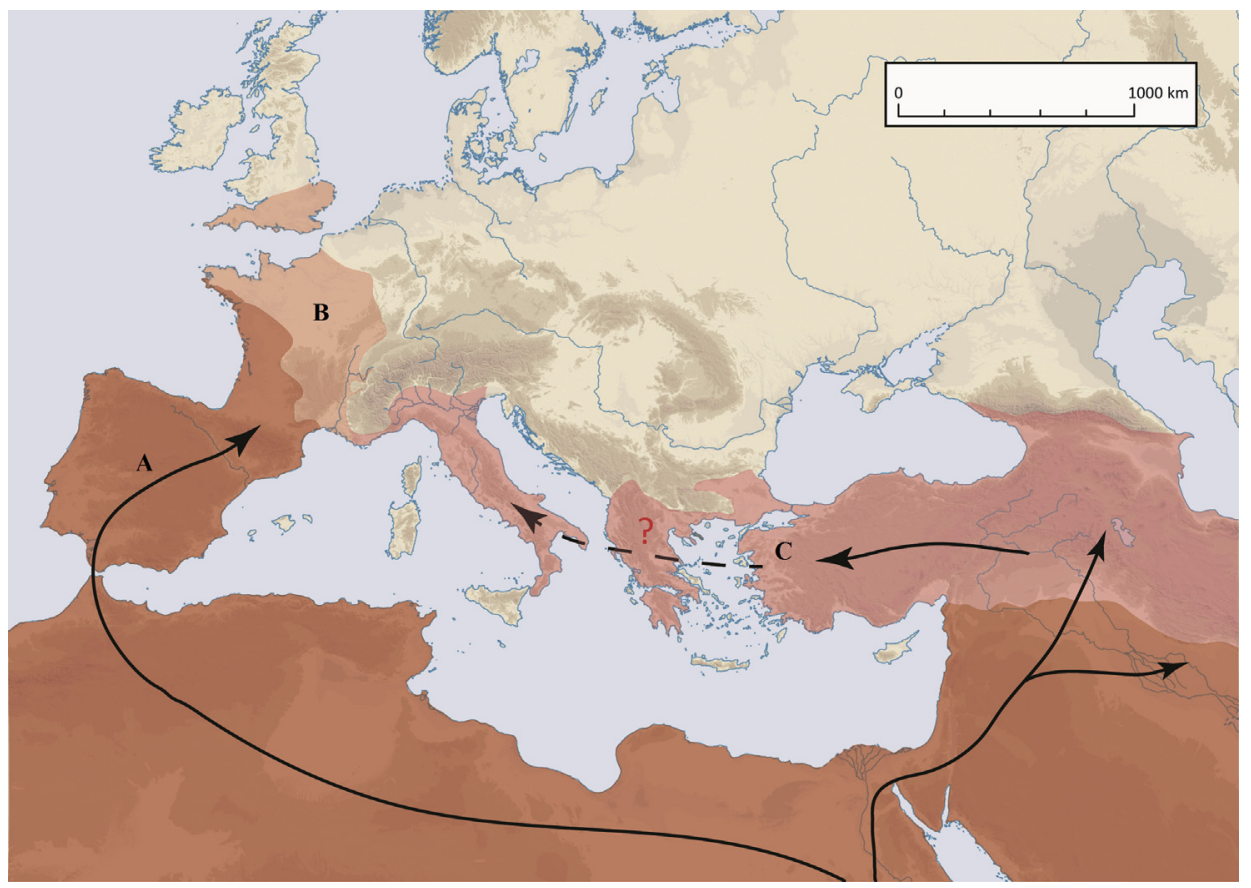

Fig. 2. Territories where the Acheulean LCT technocomplex (A) is present and Euroasiatic areas where Acheulean industries with low presence of LCTs have been recorded.

concentration of Palaeolithic sites in the Iberian Peninsula is found along the Manzanares valley, between the centre of Madrid and its confluence with the Jarama River -a $22 \mathrm{~km}$ long valley-, and in the lower section of the Jarama river. In the Tagus valley, a sequence of 12 terraces has been identified (Pérez-González et al., 1994). The Brunhes-Matuyama boundary has been established in the $+60 \mathrm{~m}$ terrace of this valley (Pérez-González et al., 1994; Pinilla et al., 1995). Also, a minimum date of 292 ka has been established by luminescence dating (quartz-OSL and pIRIR on K-feldspar) for $+25-30 \mathrm{~m}$ terrace (López-Recio et al., 2013). On the upper and middle courses of the Manzanares and Jarama valleys, 12 and 19 stepped alluvial terraces have been identified respectively (PérezGonzález, 1994). On the lower courses, terraces lower than $30 \mathrm{~m}$ have been affected by synsedimentary subsidence due to the karstic dissolution of the gypsum in the substrate. This process has produced a great thickening of the fluvial deposits, as well as superposition of deposits from different terrace levels, which can reach over $40 \mathrm{~m}$. These have been named the Complex Terrace of Butarque and Complex Terrace of Arganda respectively (PérezGonzález, 1971; Goy et al., 1989; Pérez-González et al., 2013; Panera et al., 2014). In the Jarama valley, the Brunhes-Matuyama palaeomagnetic reversal has been identified in sediments between the end of the formation of the terrace $+60-65 \mathrm{~m}$ and the initial incision of the next terrace at $+50-55 \mathrm{~m}$ (Pérez-González et al., 2013). In the Manzanares valley, the limit between the Early and the Middle Pleistocene has been tentatively established at the $+68-72 \mathrm{~m}$ terrace (Goy et al., 1989). However, judging by the previous data, the $+60 \mathrm{~m}$ terrace was probably formed at the end of the Early Pleistocene. In the Jarama river, a combination of numerical dates obtained by aminoacid racemization (AAR), together with the evolutionary state of the microvertebrates, suggest correlation of the level of the $+30-32$ m terrace, to MIS 11 or the beginning of MIS 9, the level of the $+23-24 \mathrm{~m}$ terrace to the beginning of MIS 7, and the level of the $+18-20 \mathrm{~m}$ terrace to between MIS 6 and MIS 5. In the Manzanares River valley, the $+25-30 \mathrm{~m}$ terrace has been attributed to MIS 11-12 on the basis of the presence of Megaloceros savini at the Transfesa site
(Mazo, 2010), and the visible extent of the Complex Terrace of Butarque $(\approx T+18-20 \mathrm{~m}$ ), spans from MIS 6 to MIS 4 (PérezGonzález et al., 2008; Silva et al., 2012; Sesé and López-Martínez, 2013).

\section{Table 1}

Sequence of terraces of the Tagus, Jarama and Manzanares rivers (Based on PérezGonzález, 1980, 1994; Santonja and Pérez-González, 1997; Panera et al., 2011). 1 Arganda I, II and III are units of Complex Terrace of Arganda (Pérez-González, 1971; Pérez-González et al., 2013). 2 Complex Terrace of Butarque (Goy et al., 1989; Panera et al., 2014).

\begin{tabular}{|c|c|c|c|}
\hline \multirow[t]{2}{*}{ Serie } & \multirow{2}{*}{$\frac{\text { Tagus }}{\text { Toledo }}$} & Jarama & Manzanares \\
\hline & & Mejorada - Arganda & Madrid \\
\hline \multirow[t]{2}{*}{ Holocene } & & & $+1-1.5 \mathrm{~m}$ \\
\hline & $+3-5 \mathrm{~m}$ & $+4-5 \mathrm{~m}$ & $+4-5 \mathrm{~m}$ \\
\hline \multirow[t]{2}{*}{ Late Pleistocene } & $+4-6 \mathrm{~m}$ & & $\begin{array}{l}+8 \mathrm{~m} \\
+12-15 \mathrm{~m}\end{array}$ \\
\hline & $+20 \mathrm{~m}$ & $+18-20 \mathrm{~m} / \mathrm{A} \mathrm{III}^{1}$ & $+18-20 \mathrm{~m} / \mathrm{CTB}^{2}$ \\
\hline \multirow[t]{7}{*}{ Middle Pleistocene } & & $+23-24 \mathrm{~m} / \mathrm{AII}^{1}$ & \\
\hline & $+30 \mathrm{~m}$ & & $+25-30 \mathrm{~m} / \mathrm{CTB}^{2} ?$ \\
\hline & & $+30-32 \mathrm{~m} / \mathrm{A} \mathrm{I}^{1}$ & \\
\hline & $+40 \mathrm{~m}$ & & $+35-40 \mathrm{~m}$ \\
\hline & & $+40-41 \mathrm{~m}$ & $+44-46 \mathrm{~m}$ \\
\hline & $+50 \mathrm{~m}$ & & $+52-54 \mathrm{~m}$ \\
\hline & & $+52-53 \mathrm{~m}$ & \\
\hline \multirow[t]{8}{*}{ Lower Pleistocene } & $+60 \mathrm{~m}$ & $+60-65 \mathrm{~m}$ & $\begin{array}{l}+60 \mathrm{~m} \\
+68-72 \mathrm{~m}\end{array}$ \\
\hline & $+75-80 \mathrm{~m}$ & & \\
\hline & $+85 \mathrm{~m}$ & $+82-83 \mathrm{~m}$ & $+80-85 \mathrm{~m}$ \\
\hline & $+95 \mathrm{~m}$ & $+90-100 \mathrm{~m}$ & +95 m \\
\hline & +105 m & & \\
\hline & $+115 \mathrm{~m}$ & & \\
\hline & $+125 \mathrm{~m}$ & $+125-126 \mathrm{~m}$ & \\
\hline & & $+147-148 \mathrm{~m}$ & \\
\hline
\end{tabular}

\subsection{Chronology of the Iberian Acheulean}

The Acheulean techno-complex in the Iberian Peninsula has been dated to the second half of the Middle Pleistocene, with 

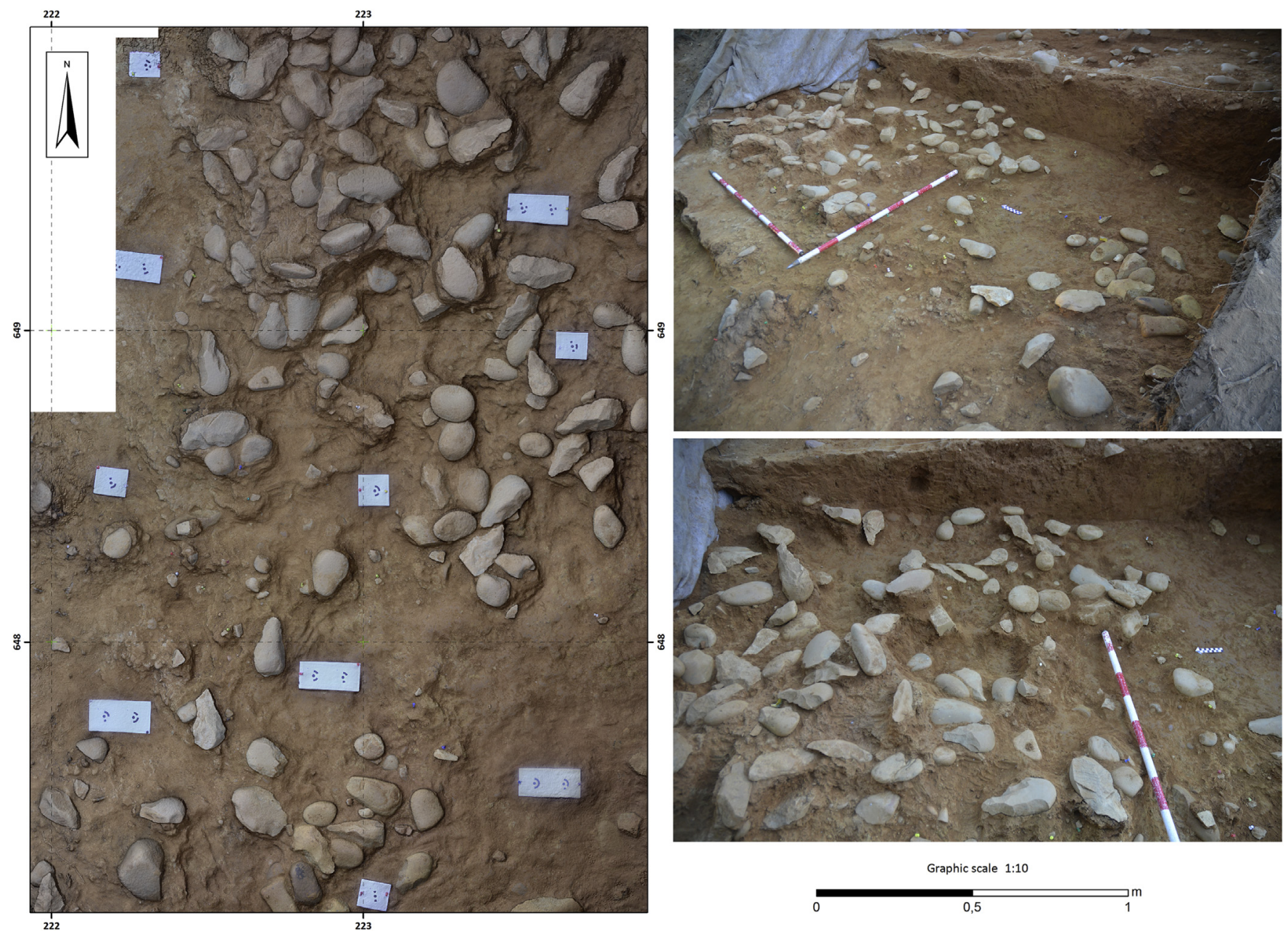

Graphic scale $1: 10$

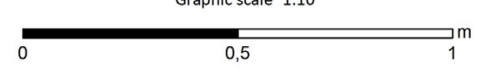

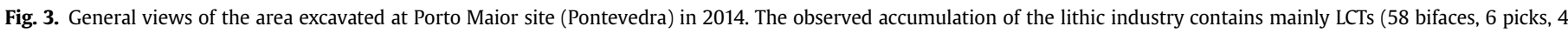
cleavers and 15 large flakes), as well as large quartzite cobbles which were brought to the site. The sedimentary environment corresponds to an overbank fluvial facies.

various chronologies indicating that it does not pre-date MIS 12 and could extend to younger than MIS 8. On occasion, industries earlier than MIS 12 have been attributed to the Acheulean techno-complex in the Iberian Peninsula. The site of Barranc de la Boella (Tarragona) preserves remains of Mammuthus meridionalis and a lithic industry in levels with reversed magnetic polarity, which have been dated by cosmogenic nuclides to between 0.87 and 1.07 Ma (Vallerdú et al., 2014). The lithic industry comes from three different places and from different levels. There are a total of nine small series which contain between 8 and 66 pieces, and a larger one (P1L level II) with 125 pieces. The last has yielded only 8 slightly retouched flakes (notches and denticulates) and a piece made on a flake of larger size, which has been identified as a pick with elemental configuration (Vallerdú et al., 2014). However, the series from La Boella, mainly consisting of broken flakes and angular fragments, does not offer clear technological features that suggest an "Early Acheulean" interpretation, even though on the African continent, Acheulean technology is perfectly developed at the time of La Boella. The presence of the Acheulean techno-complex in North Africa during the Early Pleistocene (Rhodes et al., 2006) suggests that its appearance in Europe could have occurred over a comparable chronological range, although, evidence to support such theory are so far unavailable.

In the Tajo, Jarama and Manzanares valleys, knapped stone items have been found in terraces dated to the end of the Early
Pleistocene and the first half of the Middle Pleistocene. However, the recorded lithic assemblages become more common at the $+30 \mathrm{~m}$ terrace in the Tagus valley, the $+30-32 \mathrm{~m}$ terrace in the Jarama valley, and $+25-30 \mathrm{~m}$ terrace in the Manzanares valley. Acheulean technology with large cutting tools (LCTs) has been confirmed in abundant assemblages found in all these terraces, several of which have been excavated, such as Pinedo and Puente Pino in the Tagus Valley (Querol and Santonja, 1979; Rodríguez de Tembleque et al., 2005), Transfesa/Tafesa (Baena and Baquedano, 2010) in the Manzanares Valley, and Áridos 1 and 2 in the Jarama Valley (Santonja et al., 1980). Fluvial deposition has determined the availability of raw materials used in lithic production and constitutes an important factor in the configuration of lithic types. Thus, LCTs are best represented in the Tajo and Jarama river valleys, where quartzite is abundant, as opposed to the Manzanares valley where this raw material is not available and flint is more easily found. Bifaces are generally the most frequent type of tool, followed by choppers, whereas cleavers and trihedrals are sporadically present.

In the Duero Basin, characteristic Acheulean sites are known from the $+20 \mathrm{~m}$ terrace of the Tera River, in Zamora, and in the $+22 \mathrm{~m}$ terrace of the River Tormes, in Salamanca. An indication of the probable chronology of these terraces comes from an ESR age of $230+30 \mathrm{ka}$, based on the $\mathrm{Al}$ centre measured in quartz grains obtained from a broadly equivalent terrace level $(+12-17 \mathrm{~m})$ in the 
Arlanzón River valley, Burgos (Moreno et al., 2012). In the Jarama valley, the Acheulean site of Valdocarros, located in the stratigraphic unit of Arganda II ( $=\mathrm{T}+23-24 \mathrm{~m})$, has been dated by AAR to $254 \pm 47$ and $262 \pm 7 \mathrm{ka}$ (Panera et al., 2011). In the Manzanares valley, the latest dates obtained in relation to the Acheulean industries correspond to the lowest levels of the visible extent of the Complex Terrace of Butarque, which might correspond to MIS 6. In this complex terrace, the Oxígeno archaeological site displays an extensive and characteristic Acheulean lithic series. Elsewhere, at the Acheulean sites of Torralba (Soria, Spain) and Duclos (Pyrénées Orientales, France), both of which have produced cleavers (Fig. 4), there are OSL multigrain aliquot dates of $209+22$ ka and $174+19 \mathrm{ka}$, and TT-OSL dates of $189+13 \mathrm{ka}$ (top of level BTII), and $235+17 \mathrm{ka}$ and $274+18 \mathrm{ka}$ (bottom of level BTII) respectively (Falguères et al., 2006; Hernández et al., 2012; Santonja et al., 2014a).

\section{The Middle Palaeolithic sequence of the Middle Pleistocene in the Iberian Peninsula}

From the end of MIS 9 or beginning of MIS 8, sites with European Ancient Middle Palaeolithic (EAMP) industries are known
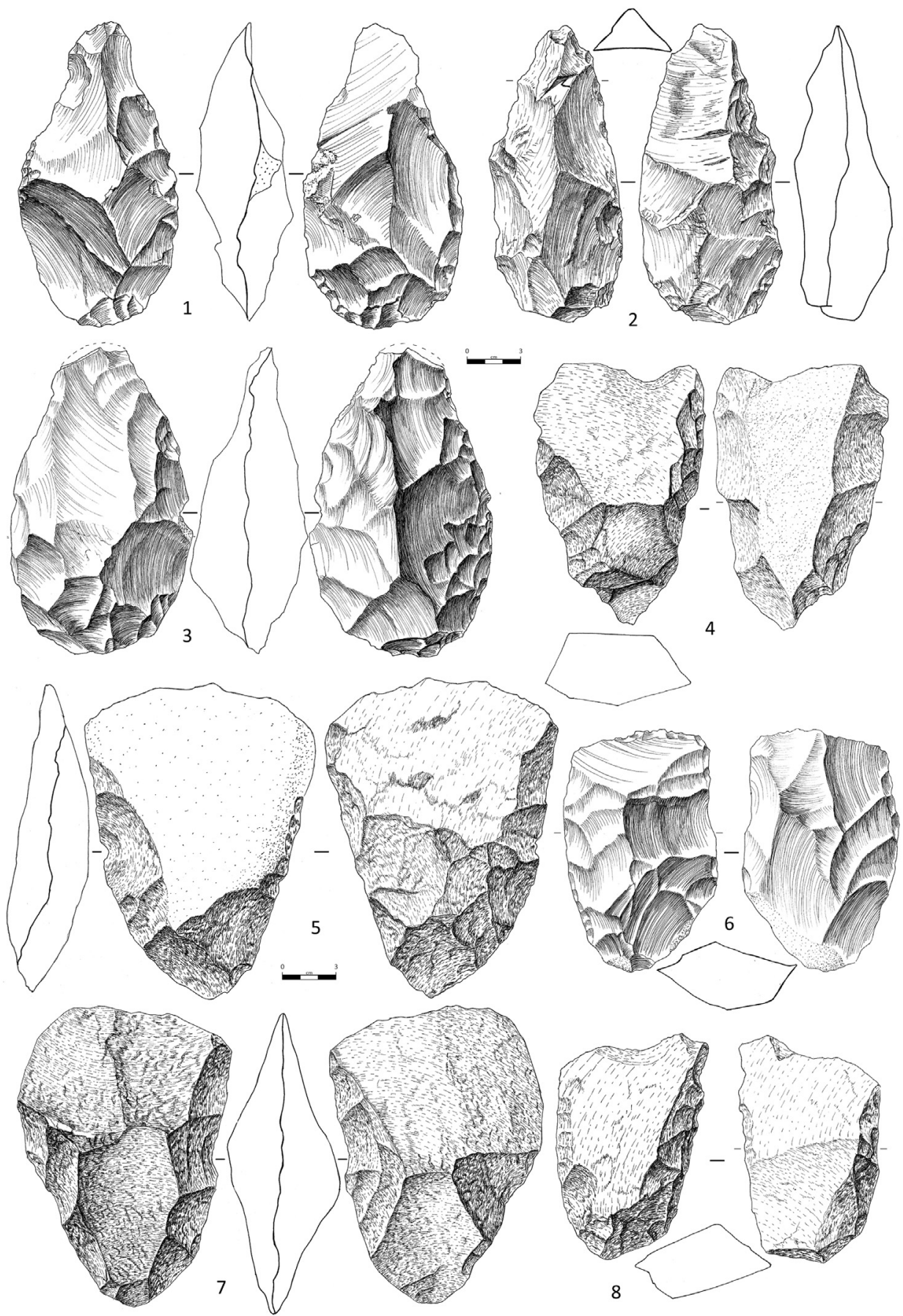

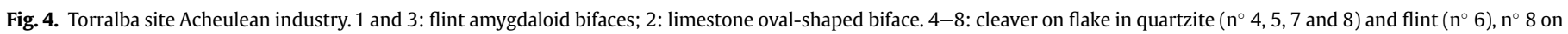

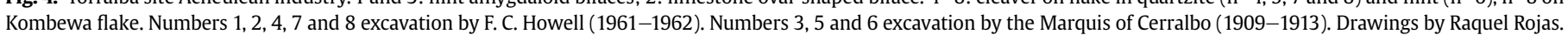


throughout southern Europe and, unlike the Acheulean, they are found both in caves and in open-air sites (Moncel et al., 2005; Bourguignon et al., 2008; Koehler, 2008; Richter, 2011). Over the last few years, the number of EAMP sites has increased significantly, especially in the Iberian Peninsula, where they were previously largely unknown. In some cases, the dates of these new EAMP sites have been attributed to MIS 10 , and they are therefore significantly earlier than some true Acheulean sites. The most representative EAMP open-air Iberian sites are Cuesta de la Bajada (Teruel), Ambrona (Soria) and Solana del Zamborino (Granada). Cave sites with representative EAMP industries include Bolomor (Valencia), Gran Dolina (Burgos), Cueva de las Grajas (Málaga) and possibly Cueva del Ángel (Córdoba).

\subsection{Cuesta de la Bajada}

The Cuesta de la Bajada site is located in the T4 terrace fluvial sequence $(+50-53 \mathrm{~m})$ of the Alfambra River. It consists of 10 fillstrath stepped terraces with relative heights ranging between $+2-3 \mathrm{~m}$ (T10, present-day floodplain), and $+103-104 \mathrm{~m}$ (T1). The results obtained using OSL $(264+22 / 293+24 \mathrm{ka})$ and ESR $(264+42 / 350+49)$ dating display good internal and crossmethodological consistency permitting the most likely age of the site to be placed in MIS 8 or 9 (243-337 ka). This chronology is also consistent with the evidence from the microfaunal evolutionary stage (Santonja et al., 2014a).

The site was formed around a pond not far from a river and contains remains of large macrofauna, such as equid, cervid and other taxa. The formation process and the presence of a considerable amount of small debris such as numerous bone fragments imply that the archaeological assemblage is essentially preserved in an autochthonous position.

The preservation of all phases of the chaîne opératoire confirms that knapping was performed in situ. The tools and flakes originated from reshaping and, together with the cut marks observed on bones, constitute clear evidence that the former were used on-site prior to being discarded. Blocks displaying traces of impact marks, especially Neogene limestone blocks, can be found together with fractured bones. Some of the percussion activities are thought to be related to the processing of animal remains (Santonja et al., 2014a).

The process of lithic production at Cuesta de la Bajada is very different from the functional solutions of the European Acheulean techno-complex, which is characterised by volumetric concepts of bifacial shaping and the production of large support flakes. Instead, Cuesta de la Bajada represents a technology focused on débitage, the application of technical concepts such as ramified production sequences (Bourguignon et al., 2004), and the recycling of flakes via resharpening of tools and exhausted cores. This kind of technology reaches its full development with the Mousterian industries, and can also be found in the preceding Middle Pleistocene Southern European core, flake and tool industries, as well as in Central Europe at sites such as Bilzingsleben, Vertesszölös and Schöningen, which have been dated to MIS 9/MIS 11 (Rocca, 2013 and references therein), similar to Cuesta de la Bajada.

\subsection{Open air sites: Ambrona middle and Solana del Zamborino}

The lithic industry of the middle stratigraphic unit of Ambrona (Rubio-Jara, 1996; Santonja and Pérez-González, 2006), which has been dated to $\sim 350 \mathrm{ka}$ by combined ESR/U-series of fossil teeth (Falguères et al., 2006), displays discoidal débitage (cf. Mourre, 2003) and the use of soft hammerstones in retouching. It also shows a reduced bifacial component, usually bifaces-tool support (Boëda, 2001) and is characterised mainly by the development of flake tools, scrapers and denticulates (Fig. 5). The industry of Solana del Zamborino (Jiménez et al., 2011), with an estimated age of $\sim 300 \mathrm{ka}$, based on the association of micro-mammals, is characterised by the development of débitage and flake tools, in association with bifaces-tool support, as described for the middle unit of Ambrona.

\subsection{Gran Dolina Atapuerca site}

The industry of the upper part of the Gran Dolina (Atapuerca complex, Burgos), the TD10 stratigraphic unit, has been interpreted during the last years as a paradigm of a supposed Mode 2/Mode 3 transition (Ollé et al., 2013). The 4 m-thick TD10 level has been divided into four subunits labelled, from top to bottom, as TD10.1/2/ $3 / 4$. The two topmost subunits have been excavated and have uncovered three sets of $\sim 50$-cm thick levels (TD10.1 Upper, TD10.1 Lower and TD10.2). ESR/U series dates obtained for the upper and lower part of TD10.1 are $337 \pm 29 \mathrm{ka}$ and $379 \pm 57 \mathrm{ka}$, respectively, whilst for TD 10.2, the corresponding dates are $337 \pm 51 \mathrm{ka}$ and $418 \pm 63$ ka (Falguères et al., 1999). These ESR/U-series dates indicate that the section was deposited sometime during late MIS 11 , MIS 10 or early MIS 9 . However, TL dating on polymineral finegrain fractions of the lower section at TD 10.2 has produced a younger age of $244 \pm 26 \mathrm{ka}$; i.e., within MIS 8 (Berger et al., 2008). The known industry of TD10.1 and TD10.2 lacks the characteristics typical of the Acheulean techno-complex and may be accepted as EAMP. The knapping systems are characterised, according to the excavators (Ollé et al., 2013), by the predominance of centripetal schemes that would also include Levallois methods. The latter, in fact, do exist at this site (see Figs. 13c and 18f of Ollé et al., 2013; also M.S. personal obs.), although the particular methodology applied to the Atapuerca assemblage (Logical-Analytical System) does not permit assessment of the data with sufficient precision. The main component of the consumption phase of the c.o. in the three levels is the transformation of flakes (by retouching) into conventional Mousterian assemblage tools. A shaped macro-industry is rare in TD10.2 and in Upper TD10.1. In Lower TD10.1, it is limited to 15 bifaces and 3 cleavers out of a total of 616 tools (2.9\%), and seems to be characterised as at Ambrona, Solana or Cueva del Ángel by bifaces-tool support (cf. Fig. 21 of Ollé et al., 2013). The industrial assemblage of TD10 is therefore considered to provide evidence of the transition between Mode 2 and Mode 3. Importantly, however, the preceding level (TD 10.2) at Dolina lacks Acheulean elements, and has been already accepted as representative of Mousterian technology (Ollé et al., 2013), an opinion with which we agree.

\subsection{Other cave sites: Bolomor, Cueva del Ángel and Las Grajas}

The cave of Bolomor (Valencia) is another site where a long occupation has been recorded, spanning from the mid-Middle Pleistocene to the beginning of the Upper Pleistocene (MIS 9 to 5). The three lower phases at this site have a Middle Pleistocene date. Phase I and Phase II (l. XIV) have been dated by AAR to $525 \pm 125 \mathrm{ka}$ and by TL to $233 \pm 35 \mathrm{ka}$ and $225 \pm 34 \mathrm{ka}$, respectively. Throughout the whole sequence, Middle Palaeolithic type industries do not indicate any influence of the Acheulean technocomplex. With the exception of the rare Levallois débitage found in Phase III (attributed to MIS 6), the industry of Bolomor is centred on the ramified production of small flake tools and exhausted cores, and shows a variability that indicates a clear economy of raw materials and of débitage (Fernández-Peris et al., 2008).

Cueva del Ángel (Córdoba), with its characteristic flake and bifaces-support Mousterian industry (Barroso-Ruiz et al., 2011, cf. Fig. 11, p. 121), offers close parallels with Solana and even with Ambrona, despite lacking Levallois débitage and having a more younger preliminary U-series age of $\sim 120 \mathrm{ka}$. The associated fauna 

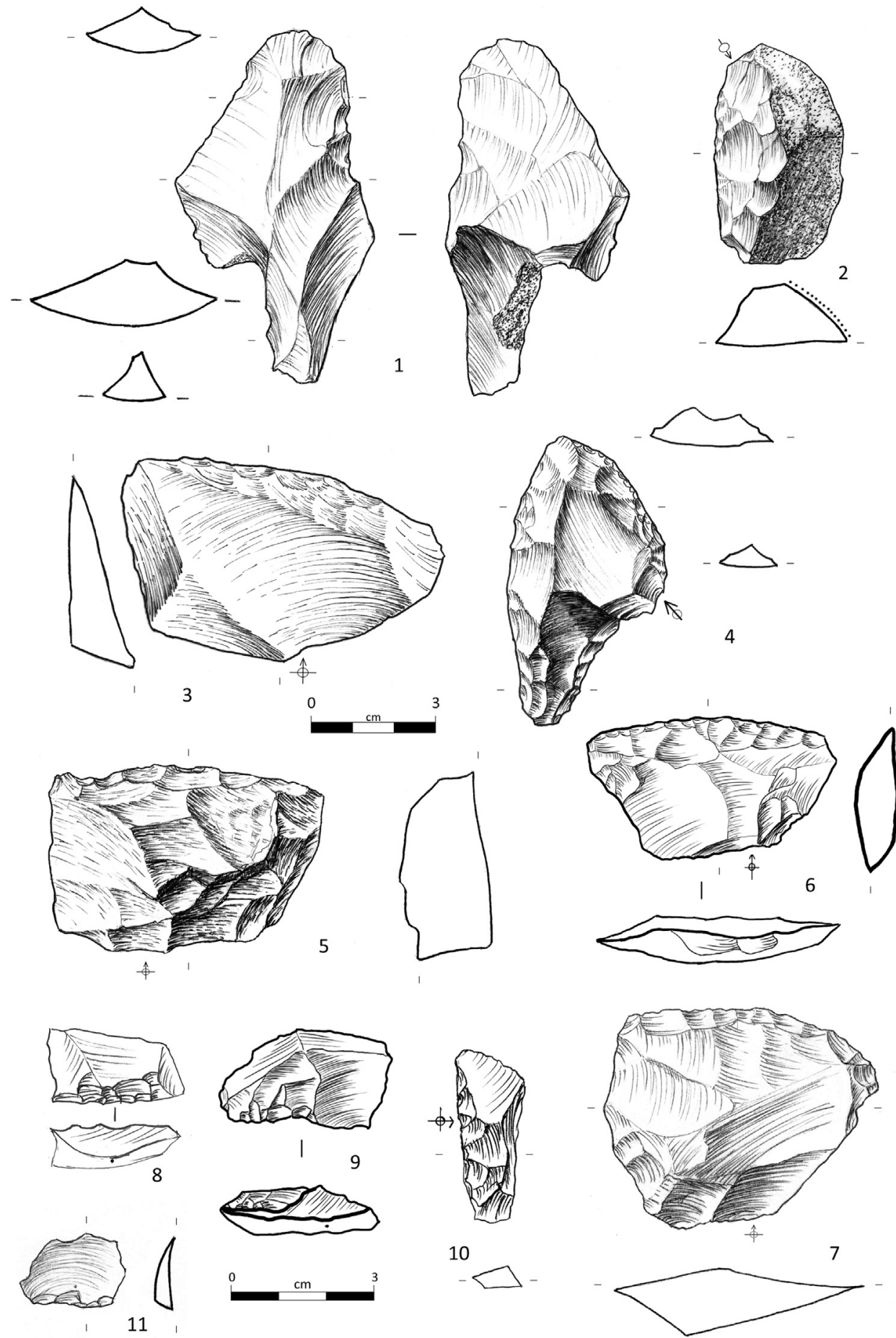

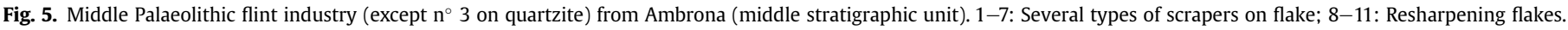
Excavation by Santonja and Pérez-González (2013-2014). Drawings by Raquel Rojas.

at Cueva del Ángel may correspond to the latest part of the Middle Pleistocene, indicating that the site may in fact be older than the Useries results suggest.

The cave of Las Grajas (Málaga), still poorly known despite having been intensively excavated between 1972 and 1976, comprises a long sequence that has been assigned to MIS 8, according to the evolutionary stage of the microfauna (Sesé and Sevilla, 1996). The industrial assemblage of Las Grajas, which completely lacks an Acheulean macro industry, has been considered as Mousterian of
non-Levallois facies (Benito del Rey, 1982), and it also includes characteristic ramification processes.

\section{Discussion and conclusions}

There is a clear coexistence of assemblages with Acheulean and Middle Palaeolithic affinities during the final third of the Middle Pleistocene in the Iberian Peninsula. According to the chronologies of Ambrona, Gran Dolina TD10, and Cuesta de la Bajada, the Middle 
Palaeolithic industry began at least as early as MIS 10/MIS 9. Similarly, the chronologies developed for Valdocarros, Torralba and the terraces around $+20 \mathrm{~m}$ of the Duero basin show that characteristic Acheulean industries were present as late as MIS 6. In the south of France, the situation seems very similar (Moncel et al., 2005; Mourre and Colonge, 2007; Bourguignon et al., 2008; Hernández et al., 2012).

In northern France, however, the frequency of the Acheulean techno-complex s.s. is lower compared to the Iberian Peninsula or Aquitaine, and the Acheulean seems to have disappeared at some point after MIS 9. From this period onwards, it can be widely shown that flake-core-tool industries collectively assigned to EAMP reached a technological development comparable to that of the Mousterian in the Upper Pleistocene (Koehler, 2008; Scott, 2010; Richter, 2011). At the same time, however, sites with flake-core industries and tools, and with chronologies spanning either the pre- or post-MIS 9 period, can be clearly recognised in central and eastern Europe, where the Acheulean has never been found (Doronichev and Golovanova, 2010; Haidle and Pawlik, 2010; Rocca, 2013).

Certainly, behavioural aspects should be taken into consideration in a discussion of the changes that occurred in the European societies of the later Middle Pleistocene (Villa, 2006, 2009; Chazan, 2009; Villa and Lenoir, 2009). However, here we focus our attention exclusively on the industry, with a particular emphasis on the theoretical evolutionary relationship between the two technological entities known to have occurred during the Ancient European Palaeolithic.

This debate has frequently been brought up independently of the dichotomy observed between the southernmost territories and the rest of the subcontinent (Monnier, 2006; Hopkinson, 2007; Moncel et al., 2011, 2012). Sequences such as that recognised in the Somme basin, north France, more than 30 years ago (Koehler, 2008; Tuffreau et al., 2008), seemed to justify the hypothesis of a transformation between the Acheulean and the Mousterian that occurred through different intermediate facies. This hypothesis is represented by situation $\mathbf{E}$ (Fig. 6) of the model discussed by Chazan (2009, cf. Fig. 1, p. 239). From MIS 8 onwards, the region is characterised by industries with heterogeneous technological balances: particularly Cambresian facies grouping assemblages with a clear Acheulean influence, Epi-Acheulean facies integrating series with some Acheulean elements and a more significant Mousterian component, and, some time later (from MIS 7 onwards), fully Mousterian industries such as Biache, Le Rissori or Therdonne,

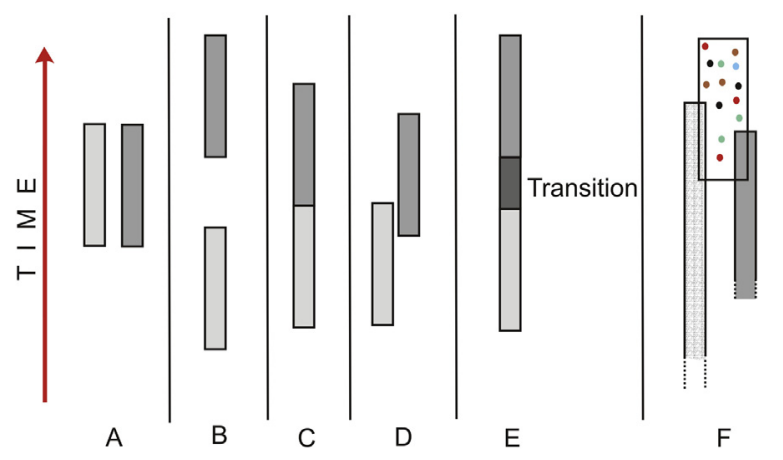

Fig. 6. Potential temporal relationships between two autonomous archaeological entities (here, techno-complexes). A. Total overlap in time. B. Clear temporal separation. C. Continuity without transitional period. D. Partial overlap in time. E. Transitional interface period. F. Partial overlap in time and mutual influences but non transitional interfaces (according to Chazan, 2009, modified). which show a normalised production of Levallois blanks (Tuffreau, 1992; Koehler, 2008; Tuffreau et al., 2008).

However, the Acheulean s.s. and Mousterian s.s. industries that coexist for around $150 \mathrm{ka}$ in the Iberian Peninsula and Aquitaine show a different situation, and appear to be more consistent with model $\mathbf{D}$ rather than model $\mathbf{E}$ of Chazan (Fig. 6). If we examine the general scenario from the south of Europe, the intrusive character of the Acheulean techno-complex in the Ancient European Palaeolithic seems evident, as has been already suggested (Otte, 2001). Under this scenario, the Acheulean would have reached Europe through Gibraltar (Santonja and Villa, 2006; Santonja and PérezGonzález, 2010) at a later date than its appearance in Africa, Middle East, India and probably SE Asia.

It would have then spread throughout Europe in territories already occupied by human groups that were, since the Early Pleistocene, developing technologies exclusively based on the exploitation of cores and natural blanks to produce flakes. This technology had its own evolutionary dynamics, and was far from any volumetric conception typical of the Acheulean (Schick, 1998; De-Bono and Goren-Inbar, 2001; Otte, 2001; Lycett and Gowlett, 2008; James and Petraglia, 2009; Lycett et al., 2010; Diez-Martín and Eren, 2012). The raw material has not been a determining factor on the production of bifaces or macro tools in any of the considered sites. This becomes particularly evident in the cases of Cuesta de la Bajada, Ambrona or Gran Dolina (Santonja y Pérez González, 2002; Ollé et al., 2013; Santonja et al., 2014a,b), which have yielded representative chaines operatoires, where the supply of raw materials occurred in areas next to the sites and where clasts of sizes (allowing manufacture of large tools) have been recorded. This is particularly evident in Ambrona, as the raw materials and their supply areas co-occur in the lower and middle stratigraphical unit, with Acheulean and Middle Palaeolithic industries respectively. Representative examples of such industries can be observed at Orce, Atapuerca-Sima, Elefante, Happisburgh 3, Atapuerca-TD6, Cueva Negra de Quípar, Isernia, La Micoque or High Lodge in Western Europe (Ashton, 1992 - contra Gibbard et al., 2009-; Peretto, 1994; Bridgland et al., 2006; Parfitt et al., 2010; Turq et al., 2010; Toro et al., 2011; Jiménez-Arenas et al., 2011; Ollé et al., 2013), and in Sinyaya Balka, Kozarnica, Stranska Skala, Korolevo, Vertesszölös, Schöningen, Bilzingsleben and Neumark Nord 3 in central and eastern Europe (Terberger, 2006; Haidle and Pawlik, 2010; Doronichev and Golovanova, 2010; Richter, 2011; Rocca, 2013). The recognition of an evolutionary dynamic in the European industries of cores and flakes allows the assessment of all these series as a non-Acheulean techno-complex of "Mode 2", an interpretation that had already been suggested for some of the lower levels of Aragó (Lumley and Barsky, 2004) and that could also be perfectly applicable to the industry of Atapuerca TD6 (cf. Ollé et el., 2013), and even more clearly to that of Isernia (Galloti and Peretto, 2015).

This scenario is equally not consistent with that developed in Chazan's model. Instead, the situation we observe across southern Europe seems to correspond better to an evolutionary process of European populations with core and flake industries that were superimposed by human groups of African origin associated with an Acheulean technology. The timing of this event corresponds to sometime during the Middle Pleistocene, certainly by MIS 12 but possibly as early as MIS 16, according to some authors (Antoine et al., 2010; Moncel, 2010). The appearance of the Acheulean technology in Europe is therefore an unresolved topic. Dates older than MIS 12 indicated for some Acheulean sites in southern Europe, such as L'Aragó (Falguères et al., 2004; Barsky and de Lumley, 2010) Notarchirico (Pilleyre et al., 1999; Lefèvre et al., 2010) - single determinations carried out a long time ago-, or La Noira (Moncel 
et al., 2013), require confirmation through implementation of other methodologies (Demuro et al., 2014).

This superimposition would have taken place in a context characterised by very low population densities, and large areas that remained almost uninhabited during the coldest periods, even in the south of Europe (Dennell et al., 2011; MacDonald et al., 2012; Bermúdez de Castro et al., 2013). The possible contacts between hominin groups, with decreasing intensity from south to north, could have produced multiple and heterogeneous responses (Fig. 6F). The lithic industries of the end of the Middle Pleistocene (MIS 8 to MIS 6) show different technological solutions which may partly come from mutual influences of both Acheulean and Middle Palaeolithic techno-complexes. These responses are difficult to identify in detail, given the geochronological control available and the information provided by the sequences and sites known to date. The non-linear evolutionary scenario we propose has a good counterpoint in recent anthropological models that recognise a variety of lineages in the European Middle Pleistocene and the African roots of $H$. heidelbergensis (Rightmire, 2008; Mounier et al., 2009; Mirazón Lahr, 2010; Tattersall, 2011) - connections that in the past have been explicitly related to the expansion of the Acheulean techno-complex (Hublin, 2009)-, as well as the significant autonomy of the Eurasian populations in relation to those of the African continent (Dennell et al., 2010; Bermúdez de Castro et al., 2013).

\section{Acknowledgements}

The authors wish to express their gratitude to the Junta de Castilla y León (Spain) and Gobierno de Aragón (Spain) for permissions to excavate the Ambrona (2013-2015) and Cuesta de la Bajada (1999-2011) archaeological sites. Research has been developed in the framework of Junta de Castilla y León projects CEN186A12.

We also thank Raquel Rojas for the drawings of lithic industry (Figs. 4 and 5). Thanks to P. Villa for her influencial and inspirational conversations during the preparation of this text. We also wish to thank editors to invite us to participate in this volume, two anonymous reviewers and Danielle Schreve for her assistance in editing this paper and constructive suggestions.

\section{References}

Antoine, P., Auguste, P., Bahain, J.J., Chaussé, C., Falguères, C., Ghaleb, B., LimondinLozouet, N., Locht, J.L., Voinchet, P., 2010. Chronostratigraphy and palaeoenvironnement of Acheulean occupations in Northern France (Somme, Seine and Yonne River valleys). Quaternary International 223-224, 456-461.

Ashton, N.M., 1992. The High Lodge flint industries. In: Ashton, N.M., Cook, J., Lewis, S.G., Rose, J. (Eds.), High Lodge: Excavations by G. de G. Sieveking 1962-8, and J. Cook, 1988. British Museum Press, London, pp. 124-163.

Baena, J., Baquedano, I., 2010. Las huellas de nuestro pasado. Estudio del yacimiento del Pleistoceno Madrileño de Tafesa (Antigua Transfesa). Zona Arqueológica 14, $141-153$.

Bar-Yosef, O., Belfer-Cohen, A., 2013. Following Pleistocene road signs of human dispersals across Eurasia. Quaternary International 285, 30-43.

Barroso Ruíz, C., Botella Ortega, D., Caparrós, M., Moigne, A.M., Celiberti, V., Testu, A. Barsky, D., Notter, O., Riquelme Cantal, J.A., Pozo Rodríguez, M., Carretero León, M.I., Monge Gómez, G., Khatib, S., Saos, T., Gregoire, S., Bailón, S., García Solano, J.A., Cabral Mesa, A.L., Djerrab, A., Hedley, I.G., Abdessadok, S., Batalla Llasat, G., Astier, N., Bertin, L., Boulbes, N., Cauche, D., Filoux, A., Hanquet, C. Milizia, C., Moutoussamy, J., Rossoni, E., Verdú Bermejo, L., de Lumley, H., 2011. The Cueva del Ángel (Lucena, Spain): an Acheulean hunters habitat in the South of the Iberian Peninsula. Quaternary International 243, 105-126.

Barsky, D., de Lumley, H., 2010. Early European Mode 2 and the stone industry from the Caune de l'Arago's archeostratigraphical levels "P". Quaternary International 223-224, 71-86.

Benito del Rey, L., 1982. Outils fracturés intentionnellement dans le Moustérien de la grotte de Las Grajas à Archidona (Málaga, Espagne). Bulletin de la Société Préhistorique Française 79 (8), 231-239.

Berger, G.W., Pérez-González, A., Carbonell, E., Arsuaga, J.L., Bermúdez de Castro, J.M., Ku, T.L., 2008. Luminescence chronology of cave sediments at the
Atapuerca paleoanthropological site, Spain. Journal of Human Evolution 55, $300-311$.

Bermúdez de Castro, J.M., Martinón-Torres, M., Blasco, R., Rosell, J., Carbonell, E., 2013. Continuity or discontinuity in the European Early Pleistocene human settlement: the Atapuerca evidence. Quaternary Science Review 76, 53-65.

Boëda, E., 1991. Approche de la variabilité des systèmes de production lithique des industries du paléolithiqueinférieuretmoyen: Chroniqued'unevariabilitéattendue. Techniques et Culture 17-18, 37-79.

Boëda, E., 2001. Determination des unités tecno-fonctinelles de pièces bifaciales provenant de la couche acheuléenne $C^{\prime} 3$ Base du site de Barbas I. In: Cliquet, D. (Ed.), Les industries à outils bifaciaux du Paléolithique moyen d'Europe occidentale, ERAUL 98, pp. 51-75.

Böeda, E., Geneste, J.-M., Meignen, L., 1990. Identification de chaînesoperatorieslithiques du Paléolithiqueancien et moyen. Paléo 2, 43-80.

Bourguignon, L., Djema, H., Bertran, P., Lahaye, Ch, Guibert, P., 2008. Le gisementsaalien de Petit-Bost (Neuvic, Dordogne) à l'origine du Moustériend'Aquitanie? In: Jaubert, J., Bordes, J.G., Ortega, I. (Eds.), Les societies du Paléolothiquedans un Grand Sud-Ouest de la France: nouveaux gisements, nouveaux resultants, nouvelles methods, Société Préhistorique française. Mémoire XLVII, pp. 41-55.

Bourguignon, L., Faivre, J.Ph, Turq, A., 2004. Ramification des chaînesopératoires: unespécifité du Moustérien? Paleo 16, 37-48.

Bridgland, D.R., Antoine, P., Limondin-Lozouet, N., Santisteban, J.I., Westaway, R., White, M.J., 2006. The Palaeolithic occupation of Europe as revealed by evidence from the rivers: data from IGCP 449. Journal of Quaternary Science 21 (5), $437-455$.

Chazan, M. 2009. Assessing the Lower to Middle Paleolithic Transition. In: Camps, M., Chauhan, P. (Eds.), Sourcebook of Paleolithic Transitions, Methods, Theories, and Interpretations. Springer, New York, pp. 237-243.

Clark, J.D., 1994. The Acheulean industrial complex in Africa and elsewhere. In: Corruccini, R., Ciochon, R. (Eds.), Integrative Paths to the Past. Prentice Hall, New Jersey, pp. 451-469.

Cunha, P.P., Martins, A.A., Huot, S., Murray, A., Raposo, L., 2008. Dating the Tejo river lower terraces in the Ródão area (Portugal) to assess the role of tectonics and uplift. Geomorphology 102, 43-54.

De-Bono, H., Goren-Inbar, N., 2001. Note of a link between Acheulian handaxes and the Levallois method. Journal of the Israel Prehistoric Society 31, 9-23.

Delagnes, A., Jaubert, J., Meignen, L., 2007. Les techno-complexes du Paléolithique moyen en Europe occidentale dans leur cadre diachronique et géographique. In: Vandermeersch, B., Maureille, B. (Eds.), Les Néandertaliens. Biologie et cultures. Editions du CTHS, Paris, pp. 213-229.

Demuro, M., Arnold, L.J., Parés, J.M., Pérez-González, A., Ortega, A.I., Arsuaga, J.L., Bermúdez de Castro, J.M., Carbonell, E., 2014. New Luminescence Ages for the Galería Complex Archaeological Site: resolving chronological uncertainties on the Acheulean Record of the Sierra de Atapuerca, Northern Spain. PLoS ONE 9 (10), e110169. http://dx.doi.org/10.1371/journal.pone, 0110169.

Dennell, R.W., Martinón-Torres, M., Bermúdez de Castro, J.M., 2010. Out of Asia: the initial colonisation of Europe in the Early and Middle Pleistocene. Quaternary International 223-224, 439.

Dennell, R.W., Martinón-Torres, M., Bermúdez de Castro, J.M., 2011. Hominin variability, climatic instability and population demography in Middle Pleistocene Europe. Quaternary Science Review 30, 1511-1524.

Diez-Martín, F., Eren, M.I., 2012. The Early Acheulean in Africa: past paradigms, current ideas, and future directions. In: Dominguez-Rodrigo, M. (Ed.), Stone Tools and Fossil Bones. Debates in the Archaeology of Human Origins. Cambridge University Press, Cambridge, pp. 310-357.

Doronichev, V., Golovanova, L., 2010. Beyond the Acheulean: a view on the Lower Paleolithic occupation of Western Eurasia. Quaternary International 223-224, 327-344.

Falguères, Ch., Bahain, J.J., Pérez-González, A., Mercier, N., Santonja, M., Dolo, J.M., 2006. The Lower Acheulian site of Ambrona, Soria (Spain): ages derived from a combined ESR/U-series model. Journal of Archaeological Science 33, 149-157.

Falguères, C., Bahain, J.J., Yokoyama, Y., Arsuaga, J.L., Bermúdez de Castro, J.M., Carbonell, E., Bischoff, J.L., Dolo, J.M., 1999. Earliest humans in Europe: the age of TD6 Gran Dolina, Atapuerca, Spain. Journal of Human Evolution 37 (3/4), 343-352.

Falguères, C., Yokoyama, Y., Shen, G., Bischoff, J.L., Ku, T.L., Lumley, H. de, 2004. New U-series dates at the Caune de l'Arago, France. Journal of Archaeological Science 31, 941-952.

Fernández Peris, J., Barciela González, V.,Blasco, R., Cuartero, F. Sañudo, P., 2008. El Paleolítico Medio en el territorio valenciano y la variabilidad tecno-económica de la Cova del Bolomor. Treballsd'Arqueologia 14, 141-169.

Galloti, R., Peretto, C., 2015. The Lower/early Middle Pleistocene small debitage productions in Western Europe: new data from Isernia La Pineta t.3c (Upper Volturno Basin, Italy). Quaternary International 357, 264-281.

García-Medrano, P., Ollé, A., Mosquera, M., Cáceres, I., Díez, C., Carbonell, E., 2014. The earliest Acheulean technology at Atapuerca (Burgos, Spain): oldest levels of the Galería site (GII Unit). Quaternary International 353, 170-194.

Geneste, J.M., 1985. Analyse lithiqued'industries moustériennes du Périgord: une approache tecnologique du comportement des groupes humains au Paléolithique moyen. Thèse de 3ème cycle. Université Bordeaux, 1, p. 572.

Gibbard, P.L., Pasanen, A.H., West, R.G., Lunkka, J.P., Boreham, S., Cohen, K.M., Rolfe, C., 2009. Late Middle Pleistocene Glaciation in East Anglia, England. Boreas 38, 504-528.

Gowlett, J.A., 1986. Culture and conceptualization: the Oldowan-Acheulean gradient. In: Bailey, G., Callow, P. (Eds.), Stone Age Prehistory: Studies in 
Memory of Charles McBurney. Cambridge University Press, Cambridge, pp. $243-260$.

Goy, J.L., Pérez-González, A., Zazo, C., 1989. Cartografía geológica del Cuaternario, geomorfología y Memoria correspondiente de la Hoja a E, 1: 50.000 de Madrid (559). Instituto Tecnológico Geológico y Minero de España, Madrid.

Groenen, M., 2008. Le Paléolithique. Le Cavalier Bleu, Paris.

Haidle, M.N., Pawlik, A.F., 2010. The earliest settlement of Germany: is there anything out there? Quaternary International 223-224, 143-153.

Hernández, M., Mercier, N., Bertran, P., Colonge, D., Lelouvier, L.A., 2012. Premiers éléments de datations des industries du Pléistocène moyen (AcheuléenPaléolithique moyen ancien) de la région pyréneo-garonnaise: une approche géochronologique pluri-méthodes (TL, OSL et TT-OSL) des sites de Duclos et Romentères. Paleo 23, 155-170.

Hoffmann, D.L., Pike, A.W.G., Wainer, K., Zilhao, J., 2013. New U-series results for speleogenesis and the Palaeolithic archaeology of the Almonda karstic system (Torres Novas, Portugal). Ouaternary International 294, 168-182.

Hopkinson, T., 2007. The transition from the Lower to the Middle Palaeolithic in Europe and the incorporation of difference. Antiquity 81, 294-307.

Hublin, J.J., 2009. The origin of Neandertals. PNAS 106 (38), 16022-16027.

Inizan, M.-L., Roche, H., Tixier, J., 1992. Technology of Knapped Stone. CREP, C.N.R.S, Meudon.

Isaac, G.L., 1969. Studies of early culture in East Africa. World Archaeology 1, 1-28.

Isaac, G.L., 1972. Chronology and tempo of cultural change during the Pleistocene. In: Bishop, W., Miller, J. (Eds.), Calibration of Human Evolution. Scottish Academic Press, Edinburgh, pp. 381-430.

James, H., Petraglia, M., 2009. The Lower to Middle Palaeolithic Transition in South Asia and its implications for Hominin cognition and dispersal. In: Camps, M. Chauhan, P. (Eds.), Sourcebook of Paleolithic Transitions, Methods, Theories, and Interpretations. Springer, New York, pp. 255-264.

Jaubert, J., 1999. Chasseurs et artisans du Moustérien. La Maison des Roches, Paris. Jaubert, J., Servelle, Ch, 1996. L'Acheuléen dans le basin de La Garonne (région MidiPyrénées): état de la question et implications. In: Tuffreau, A. (Ed.), L'Acheuléen dans l'Ouest de l'Europe. Publications du CERP no 4, pp. 77-108.

Jiménez-Arenas, J.M., Santonja, M., Botella, M., Palmqvist, P., 2011. The oldest handaxes in Europe: fact or artefact? Journal of Archaeological Science 38, 3340-3349.

Koehler, H., 2008. L'apport du gisement des Osiers à Bapaume (Pas-de-Calais) au débat sur l'émergence du Paléolithique moyen dans le Nord de la France. Bulletin de la Société Préhistorique Française 105 (4), 709-735.

Lefèvre, D., Raynal, J.P., Vernet, G., Kieffer, G., Piperno, M., 2010. Tephro-stratigraphy and the age of ancient Southern Italian Acheulean settlements: the sites of Loreto and Notarchirico (Venosa, Basilicata, Italy). Quaternary International 223-224, 360-368.

López-Recio, M., Silva, P.G., Cunha, P.P., Tapias, F., Roquero, E., Morín, J.., Carrobles, J., Murray, A.S., Buylaert, J.P., 2013. Dataciones por luminiscencia de la terraza $+25-30 \mathrm{~m}$ del río Tajo en el área de Toledo. El yacimiento achelense de Pinedo. In: Baena, R., Fernández, J.J., Guerrero, I. (Eds.), El Cuaternario Ibérico: investigación en el s. XXI. VIII Reunión de Cuaternario Ibérico. AEQUA, Sevilla, pp. 17-21.

Lumley, H. de, Barsky, D., 2004. Évolution des caractères technologiques et typologiques des industries lithiques dans la stratigraphie de la Caune de l'Aragó. L'Anthropologie 108, 185-237.

Lycett, S.J., Golwlett, J.A.J., 2008. On questions surrounding the Acheulean tradition. World Archaeology 40, 295-315.

Lycett, S.J., von Cramon-Taubadel, N., Gowlett, J.A.J., 2010. A comparative 3D geometric morphometric analysis of Victoria West cores: implications for the origins of Levallois technology. Journal of Human Evolution 37, 1110-1117.

MacDonald, K., Martinón-Torres, M., Dennell, R.W., Bermúdez de Castro, J.M., 2012. Discontinuity in the record for hominin occupation in south-western Europe: implications for occupation of the middle latitudes of Europe. Quaternary International 271, 84-97.

Martins, A.A., Cunha, P.P., Buylaert, J.P., Huot, S., Murray, A., Dinis, P., Stokes, M. 2010. K-Feldspar IRSL dating of a Pleistocene river terrace staircase sequence of the Lower Tajo River (Portugal, western Iberia). Quaternary Geochronology 5, $176-180$.

Martins, A.A., Cunha, P.P., Huot, S., Murray, A., Buylaert, J.P., 2009. Geomorphological correlation of the tectonically displaced Tejo River terraces (Gaviao-Chamusca area, central Portugal) supported by luminescence dating. Quaternary International 199, 75-91.

Mazo, A.V., 2010. Los macrovertebrados del Pleistoceno Medio del yacimiento de TAFESA (Madrid). In: Baena, J., Baquedano, I. (Eds.), Las huellas de nuestro pasado. Estudio del yacimiento del Pleistoceno Madrileño de Tafesa (Antigua Transfesa), Zona Arqueológica 14, pp. 141-153.

Mirazón Lahr, M., 2010. Saharan Corridors and their role in the evolutionary geography of 'Out of Africa I'. In: Fleagle, J.G., Shea, J.J., Grine, F.E., Baden, A.L. Leakey, R.E. (Eds.), Out of Africa I: the First Hominin Colonization of Eurasia. Springer Science+Business Media BV, pp. 27-45.

Molines, N., Hinguant, St, Monnier, J.-L., 2001. Le Paléolithique moyen à outils bifaciaux dans l'Ouest de la France: synthèse des donnéesanciennes et récentes. In: Cliquet, D. (Ed.), Les industries à outilsbifaciaux du Paléolithique moyen d'Europeoccidentale, ERAUL 98, pp. 107-113.

Moncel, M.H., 2010. Oldest human expansions in Eurasia: favouring and limiting factors. Quaternary International 223-224, $1-9$.

Moncel, M.H., Despriée, J., Voinchet, P., Tissoux, H., Moreno, D., Bahain, J.J., Falguères, C., 2013. Early evidence of Acheulean Settlement in Northwestern
Europe-La Noira Site, a 700000 Year-Old Occupation in the Center of France. PloS one 8 (11), e75529.

Moncel, M.H., Moigne, A.M., Combier, J., 2005. Pre-Neanderthal behaviour during isotopic 9 and beginning of stage 8. New data concerning fauna and lithics in the different occupation levels of Orgnac 3 (Ardèche, South-East France). Journal of Archaeological Science 32, 1283-1301.

Moncel, M.H., Moigne, A.M., Combier, J., 2012. Towards the Middle Palaeolithic in Western Europe: the case of Orgnac 3 (Southeastern France). Journal of Human Evolution 63 (5), 653-666.

Moncel, M.H., Moigne, A.M., Sam, Y., Combier, J., 2011. The emergence of Neanderthal technical behavior: new evidence from Orgnac 3 (Level 1, MIS 8), Southeastern France. Current Anthropology 52, 37-75.

Monnier, G., 2006. The Lower Paleolithic Periodization in Western Europe. An Evaluation. Current Anthropology 47, 709-744.

Moreno, D., Falguères, Ch., Pérez-González, A., Duval, M., Voinchet, P., BenitoCalvo, A., Ortega, A.I., Bahain, J.J., Sala, R., Carbonell, E., Bermúdez de Castro, J.M. Arsuaga, J.L., 2012. ESR chronology of alluvial deposits in the Arlanzón valley (Atapuerca, Spain): contemporaneity with Atapuerca Gran Dolina site. Quaternary Geochronology 10, 418-423.

Mounier, A., Marchal, F., Condemi, S., 2009. Is Homo heidelbergensis a distinct species? New insight on the Mauer mandible. Journal of Human Evolution 56 219-246.

Mourre, V., 2003. Discoïde ou pas Discoïde? Reflexionssur la pertinente des critères techniques définissant le debitage Discoïde. In: Peresani, M. (Ed.), Discoid Lithic Technology. Advances and Implications, Oxford, BAR Int. Series 1120, pp. 1-17.

Mourre, V., Colonge, D., 2007. Et si l'Acheuléen meridional n'était pas là où on l'attendait?. In: Un siècle de construction du discours scientifique en Préhistoire. Société Préhistorique Française, Centennial Congress, pp. 63-78.

Nicoud, E., 2013. Le paradoxe Acheuléen. In: Documents préhistoriques 32. Comité des travaux historiques et scientifiques, Paris.

Ollé, A., Mosquera, M., Rodríguez, X.P., de Lombera-Hermida, A., García-Antón, M.D. García-Medrano, P., Peña, L., Menéndez, L., Navazo, M., Terradillos, M., Bargalló, A., Márquez, B., Sala, R., Carbonell, E., 2013. The Early and Middle Pleistocene Technological Record from Sierra de Atapuerca (Burgos, Spain). Quaternary International 295, 138-167.

Otte, M., 1996. Le Paléolithique Inférieur et Moyen en Europe. Armand Colin, Paris. Otte, M., 2001. Europe and Africa during the Paleolithic. In: Miliken, S., Cook, J. (Eds.), A Very Remote Period Indeed. Papers on the Paleolithic Presented to Derek Roe. Oxbox Book, Oxford, pp. 74-77.

Panera, J., Rubio-Jara, S., Blain, H.A., Sesé, C., Pérez-González, A., 2014. Manzanares Valley (Madrid, Spain): a good country for Proboscideans and Neanderthals. Quaternary International 326-327, 329-343.

Panera, J., Torres, T., Pérez-González, A., Ortiz, J.E., Rubio-Jara, S., Uribelarrea, D. 2011. Geocronología de la Terraza Compleja de Arganda en el valle del río Jarama (Madrid, España). Estudios Geológicos 67 (2), 495-504.

Parfitt, S.A., Ashton, N.M., Lewis, S.G., Abel, R.L., Coope, G.R., Field, M.H., Gale, R. Hoare, P.G. Larkin, N.R., Lewis, M.D., Karloukovski, V., Maher, B.A., Peglar, S.M. Preece, R.C. Whittaker, J.E., Stringer, C.B. 2010. Early Pleistocene human occupation at the edge of the boreal zone in northwest Europe. Nature 466, 229-233.

Peretto, C. (Ed.), 1994. Le industrie litiche del giacimento paleolitico di Isernia La Pineta, la tipologia, le tracce di utilizzazione, la sperimentazione. Istituto Regionale per gli Studi Storici del Molise «V. Cuoco». Cosmo Iannone Editore, Isernia, p. 493.

Pérez-González, A., 1971. Estudio de los procesos de hundimiento en el valle del río Jarama y sus terrazas (nota preliminar). Estudios Geológicos XXVII (4), 317-324.

Pérez-González, A., 1980. Geología y estratigráfía de los yacimientos de Aridos en la llanura aluvial de Arganda (Madrid). In: Santonja, M., López, M., PérezGonzález, A. (Eds.), Ocupaciones achelenses en el valle del Jarama. Arqueología y Paleontología, I. Diputación Provincial de Madrid, pp. 49-61.

Pérez-González, A., 1994. Depresión del Tajo. In: Elorza, Gutiérrez (Ed.), Geomorfología de España, Rueda, pp. 389-436.

Pérez-González, A., Gallardo-Millán, J.L. Uribelarrea del Val, D., Panera, J., RubioJara, S., 2013. La inversión Matuyama-Brunhes en la secuencia de terrazas de río Jarama entre Velilla de San Antonio y Altos de la Mejorada, al SE de Madrid (España). Estudios Geológicos 69 (1), 35-46.

Pérez-González, A., Rubio-Jara, S., Panera, J., Uribelarrea, D., 2008. Geocronología de la sucesión arqueoestratigráfica de Los Estragales en la Terraza Compleja de Butarque (Valle del río Manzanares, Madrid). Geogaceta 45, 39-42.

Perlès, C. 1991. Économie des matièrespremières et économie du débitage: deux conceptions opposées?. In: 25 Ans d'Études technologiques en Prèhistoire XIe. Rencontres Internationales d'Archéologie et d'Histoire d'Antibes. Éditions APDCA, pp. 35-45.

Pilleyre, Th., Sanzelle, S., Fain, S., Miallier, D., Montret, M., 1999. Essai de datationpar thermoluminescence des dépôts du site acheuléen de Notarchirico. In: Notarchirico. Un sito del Pleistocene medio-antico nel bacino di Venosa (Basilicata), Osanna, pp. 235-243. Venosa.

Pinilla, L., Pérez-González, A., Sopeña, A., Parés, J.M., 1995. Fenómenos de hundimientos sinsedimentarios en los depósitos cuaternarios del río Tajo en la cuenca de Madrid (Almoguera-Fuentidueña de Tajo). In: Aleixandre, T., Pérez González, A. (Eds.), Reconstrucción de paleoambientes y cambios climáticos durante el Cuaternario, pp. 125-139.

Querol, M.A., Santonja, M., 1979. El yacimiento Achelense de Pinedo (Toledo). Excavaciones Arqueológicas en España. Ministerio de Cultura, Madrid, pp. 106-181. 
Rhodes, E.F., Singarayer, J.S., Raynal, J.P., Westaway, K.E., Sbihi-Alaoui, F.Z., 2006 New age estimates for the Palaeolithic assemblages and Pleistocene succession of Casablanca, Morocco. Quaternary Science Reviews 25, 2569-2585.

Richter, J., 2011. When Did the Middle Palaeolithic Begin? In: Conard, N.J., Richter, J (Eds.), Neanderthal Lifeways, Subsistence and Technology: One Hundred Fifty Years of Neanderthal Study, Vertebrate Paleobiology and Paleoanthropology. Springer Science+Busin ess Media B.V, pp. 7-14.

Rightmire, G., 2008. Homo in the Middle Pleistocene. Hypodigms, variation and species recognition. Evolutionary Anthropology 17 (1), 8-21.

Rocca, R., 2013. Peut-on definir des aires culturelles au Paléolithique inferieur? Originalité des premières industries lithiques en Europe central dans le cadre du peuplement de l'Europe. Thèse. Université de Paris Ouest Nanterre La Défense.

Rodríguez de Tembleque, J.M., Santonja, M., Pérez-González, A., 2005. Puente Pino: Un yacimiento achelense en Alcolea de Tajo (Toledo, España). In: Santonja, M., Pérez-González, A., Machado, M.J. (Eds.), Geoarqueología y Conservación de Patrimonio en la Península Ibérica y el Entorno Mediterráneo, pp. 283-295.

Roebroeks, W., 2006. The human colonization of Europe: where are we? Journal of Quaternary Science 21 (5), 425-435.

Rolland, N., 2010. The earliest hominid dispersals beyond Subsaharan Africa: a survey of underlying causes. Quaternary International 223-224, 54-64.

Rubio-Jara, S., 1996. Identificación de cadenas operativas líticas en el Complejo Superior de Ambrona (Soria). Complutum 7, 37-50.

Sackett, J.R., 1981. From de Mortillet to Bordes: a century of French Paleolithic research. In: Daniel, G. de (Ed.), Towards a History of Archaeology. Thames and Hudson, London, pp. 85-99.

Santonja, M., López, N., Pérez- González, A. (Eds.), 1980. Ocupaciones achelenses en el valle del Jarama. Arqueología y Paleontología, I. Diputación Provincial de Madrid.

Santonja, M., Pérez-González, A., 1997. Los yacimientos achelenses en terrazas fluviales de la Meseta Central española. In: Rodríguez Vidal, J. (Ed.), Cuaternario Ibérico. Huelva, pp. 224-234.

Santonja, M., Pérez-González, A., 2002. El Paleolítico inferior en el interior de la Península Ibérica. Punto de vista desde la geoarqueología. Zephyrus 53-54, $27-77$.

Santonja, M., Pérez-González, A., 2006. La industria lítica del miembro estratigráfico medio de Ambrona (Soria, España) en el contexto del Paleolítico Antiguo de la Península Ibérica. Zephyrus LIX, 7-20.

Santonja, M., Pérez-González, A., 2010. Mid-Pleistocene Acheulean industrial complex in the Iberian Peninsula. Quaternary International 223-224, 154-161.

Santonja, M. Pérez-González A. Domínguez-Rodrigo, M., Panera, J., Rubio-Jara, S. Sesé, C., Soto, E., Arnold, L.J., Duval, M., Demuro, M., Ortiz, J.E., de Torres, T., Mercier, N., Barba, R., Yravedra, J., 2014a. The Middle Paleolithic site of Cuesta de la Bajada (Teruel, Spain): a perspective on the Acheulean and Middle Paleolithic techno-complexes in Europe. Journal of Archaeological Science 49, 556-571.

Santonja, M., Pérez-González, A., Panera, J., Rubio-Jara, S., Sesé, C., Soto, E., SánchezRomero, L., 2014b. Ambrona and Torralba archaeological and paleontological sites, Soria Province. In: Sala, R (Ed) Pleistocene and Holocene Hunter-Gatherers in Iberia and the Gibraltar Strait. The Current Archaeological Record. Universidad de Burgos and Fundacion Atapuerca, Burgos, pp. 517-527.

Santonja, M., Villa, P., 2006. The Acheulean of Western Europe. In: Goren-Inbar, N. Sharon, G. (Eds.), Axe Age. Acheulean Toolmaking from Quarry to Discard. Equinox, London, pp. 429-478.

Schick, K., 1998. A comparative perspective on Paleolithic cultural patterns. In: Akazawa, T, Aoki, K. Bar-Yosef, O. (Eds.), Neandertals and Modern Humans in Western Asia. Plenum Press, New York, pp. 449-460.

Scott, B., 2010. Becoming Neanderthals. The Earlier British Middle Palaeolithic Oxbow Books, Oxford and Oakville, p. 248.
Sesé, C., López-Martínez, N., 2013. Nuevos datos paleontológicos del Pleistoceno en el Valle del Manzanares (Madrid, España): los micromamíferos del yacimiento de Arriaga. Estudios Geológicos 69 (2), 271-282.

Sesé, C., Sevilla, P., 1996. Los micromamíferos del Cuaternario peninsular español: Cronoestratigrafía e implicaciones bioestratigráficas. Revista Española de Paleontología, $N^{\circ}$ Extraordinario 278-287.

Sharon, G., 2007. Acheulean Large Flake Industries: Technology, Chronology, and Significance. In: BAR, International Series 1701. Hadrian Books, Oxford.

Silva, P.G., López-Recio, M., Tapias, F., Roquero, E., Morín, J., Rus, I. Carrasco-García, P. Giner-Robles, J.L., Rodríguez-Pascua, M.A., Pérez-López, R., 2012. Stratigraphy of the Arriaga Palaeolithic sites. Implications for the geomorphological evolution recorded by thickened fluvial sequences within the Manzanares River valley (Madrid Neogene Basin, Central Spain). Geomorphology 196, 138-161.

Soressi, M., Geneste, J.-M., 2011. The history and efficacy of the Chaîne Opératoire Approach to Lithic analysis: studying techniques to reveal past societies in an evolutionary perspective. PaleoAnthropology 2011, 334-350.

Tattersall, I., 2011. Before the Neanderthals: hominid evolution in Middle Pleistocene Europe. In: Condemi, S., Weniger, G.C. (Eds.), Continuity and Discontinuity in the Peopling of Europe. One Hundred Fifty Years of Neanderthal Study. Springer Science+Business Media B. V, pp. 47-66.

Terberger, T., 2006. From the first humans to the Mesolithic hunters in the northern German lowlands - current results trends. In: Hansen, K.M., Pedersen, K.B. (Eds.), Across the Western Baltic. Proceedings from an Archaeological Conference in Vordingborg. Sydsjællands Museums Publikationer I, pp. 23-56.

Toro, I., Barsky, D., Cauche, D., Celiberti, V., Grégoire, S., Lebegue, F., Moncel, M.H., Lumley, H. de, 2011. The archaic stone tool industry from Barranco León and Fuente Nueva 3 (Orce, Spain): evidence of the earliest hominin presence in southern Europe. Quaternary International 243, 80-91.

Tuffreau, A., 1992. Middle Palaeolithic settlement in Northern France. In: Dibble, H., Mellars, P. (Eds.), The Middle Palaolithic: Adaptation, Behavior and Variability, University Museum Symposium Series IV. University of Pennsilvania, Philadelphia, pp. 59-73.

Tuffreau, A., 2004. L'Acheuléen: de l'Homo erectus à l'homme de Néanderthal (La Maison des Roches. Paris).

Tuffreau, A., Lamotte, A., Goval, E., 2008. Les industries acheuléennes de la France septentrionale. L'Anthropologie 112, 104-139.

Turq, A., Brenet, M., Colonge, D., Jarry, M., Lelouvier, L.A., O'Farrel, M., Jaubert, J. 2010. The first human occupations in southwestern France: a revised summary twenty years after the Abbeville/Saint Riquier colloquium. Quaternary International 223-224, 383-398.

Vallverdú, J., Saladié, P., Rosas, A., Huguet, R., Cáceres, I., Mosquera, M., GarciaTabernero, A., Estalrrich, A., Lozano-Fernández, I., Pineda-Alcalá, A., Carrancho, A., Villalaín, J.J., Bourlès, D., Braucher, R., Lebatard, A., Vilalta, J., Esteban-Nadal, M., Bennàsar, M.L., Bastir, M., López-Polín, L., Ollé, A., Vergés, J.M., Ros-Montoya, S., Martínez-Navarro, B., García, A., Martinell, J., Expósito, I., Burjachs, F., Agustí, J., Carbonell, E., 2014. Age and date for Early Arrival of the Acheulian in Europe (Barranc de la Boella, la Canonja, Spain). PLoS ONE 9 (7), e103634. http://dx.doi.org/10.1371/journal.pone.0103634.

Villa, P., 2006. Pursuing Neandertals. Review of Archaeology 27, 1-25.

Villa, P., 2009. The Lower to Middle Paleolithic Transition. In: Camps, M., Chauhan, P. (Eds.), Sourcebook of Paleolithic Transitions, Methods, Theories, and Interpretations. Springer, New York, pp. 265-270.

Villa, P., Lenoir, M., 2009. Hunting and hunting weapons of the Lower and Middle Paleolithic of Europe. In: Hublin, J.J., Richards, M. (Eds.), The Evolution of Hominid Diets: Integrating Approaches to the Study of Palaeolithic Subsistence. Springer Science and Business Media B.V, pp. 59-85. 